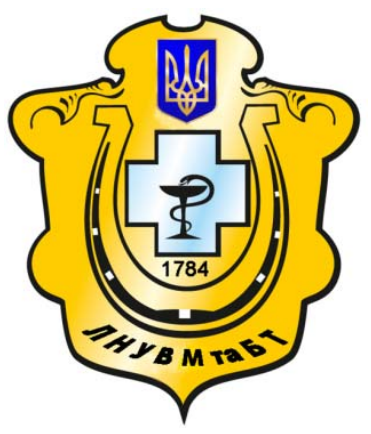

Науковий вісник Львівського національного університету ветеринарної медицини та біотехнологій імені С.3. Гжицького

Scientific Messenger of Lviv National University of Veterinary Medicine and Biotechnologies named after S.Z. Gzhytskyj

doi:10.15421/nvlvet6916

ISSN 2413-5550 print

ISSN 2518-1327 online

http://nvlvet.com.ua/

УДК 336: 764(477)

\title{
Біржовий ринок України та перспективи розвитку
}

\author{
Н.Р. Кубрак, С.М. Ткач, I.Р.Урбан \\ kubrakn@ukr.net
}

\begin{abstract}
Львівський національний університет ветеринарної медицини та біотехнологій імені С.3. Гюицького, вул. Пекарська, 50, м. Львів, 79010, Україна
\end{abstract}

\begin{abstract}
У статті оцінений сучасний стан біржового ринку Украйни та розглянуті чинники, які зумовлюють його неефективне функиіонування. Здійснено аналіз сучасного стану біржової торгівлі та виявлено проблеми формування та функиіонування біржового аграрного ринку. Визначено вплив зовнішніх факторів та якості нормативно-правового забезпечення на діяльність бірж. Розглянуто роль товарної біржі як важливої складової інфраструктури аграрного ринку. Оскільки товарна біржа призначена для постачання сировини та стабілізачії майбутньої цінової ситуації на ринку сировини, яка використовується підприємствами для подальшої переробки та реалізації на ринку споживчих товарів, то в Украӥні зростають роль та значення товарних бірж. Проаналізовано динаміку біржової активності.

Проаналізовано дані та зіставлено їх з мікро- та макроекономічними показниками діяльності намої краӥни, щзо доводить відсутність в Україні сегменту біржового ринку, не зважаючи на рекордну кількість підприємницьких організацій $з$ назвою «біржа», який виконував би притаманні йому важливі ринкові функиії.

Наведено перелік проблем розвитку біржової діяльності в Україні та необхідність чіткого механізму державного регулювання біржової діяльності.

Звернено увагу на необхідність створення єдиної біржової системи в Украӥні згідно світового досвіду.

Ключові слова: аграрний ринок, біржа, біржова торгівля, біржова угода, нормативно-правове забезпечення, біржовий
\end{abstract} ринок ,товарна біржа .

\section{Биржевой рынок Украины и перспективы развития}

\author{
Н.Р. Кубрак, С.М. Ткач, И.Р. Урбан \\ kubrakn@ukr.net
}

Львовский национальный университет ветеринарной медицины и биотехнологий имени С.3. Гюицкого, ул. Пекарская, 50, г. Львов, 79010, Украина

В статье оценено современное состояние биржевого рынка Украины и рассмотрены факторы, которые обусловливают его неэффективное функиионирование. Проведен анализ современного состояния биржевой торговли и выявлены проблемы формирования и функиионирования биржевого аграрного рынка. Определено влияние внешних факторов и качества нормативно-правового обеспечения на деятельность бирж. Рассмотрены роль товарной биржи как важной составляющей инфраструктуры аграрного рынка. Поскольку товарная биржа предназначена для поставки сырья и стабилизации будущей ценовой ситуачии на рынке сырья, которое используется предприятияли для дальнейшей переработки и реализации на рынке потребительских товаров, то в Украине возрастают роль и значение товарных бирж. Проанализирована динамика биржевой активности.

Проанализированы данные и сопоставлены их с микро- и макроэкономическими показателями деятельности нашей страны, доказано отсутствие в Украине сегмента биржевого рынка, несмотря на рекордное количество предпринимательских организаций под названием «биржа», который выполнял бы присущие ему важные рыночные функции.

Приведен перечень проблем развития биржевой деятельности в Украине и необходимость четкого механизма государственного регулирования биржевой деятельности.

\section{Citation:}

Kubrak, N., Tkach, S., Urban, I. (2016). The exchange market of ukrainian and current state. Scientific Messenger LNUVMBT named after S.Z. Gzhytskyj, 18, 2(69), 84-86. 
Обрамено внимание на необходимость создания единой биржевой системы в Украине согласно мировому опыту.

Ключевые слова: аграрный рынок, биржа, биржевая торговля, биржевая сделка, нормативно-правовое обеспечение, биржевой рынок, товарная биржа.

\title{
The exchange market of Ukrainian and current state
}

\author{
N. Kubrak, S. Tkach, I. Urban \\ kubrakn@ukr.net \\ Lviv National University of Veterinary Medicine and Biotechnologies named after S.Z. Gzhytskyi,
Pekarska Str., 50, Lviv, 79010, Ukraine
}

Exchange operations in Ukraine are still in its infancy, despite the positive trend of many indicators that characterize it. Today in Ukraine registered 584 universal, stock, commodity and agricultural exchanges, significantly more than in the USA and other countries with developed economies. Further development of exchange and OTC activity prevents a number of problems, ranging from low liquidity and low stock culture in the country and ending opacity exchange markets and imperfect regulation. Given the important role of exchange activities in the modern financial and economic system, because of solving existing problems in this area is important. Ukrainian stock market received the proper economic environment started to solve the problem of market prices based on supply and demand. Gradually, the process of self-destruction shadow market of agricultural, industrial, mining products through transparency of trade flows. This can increase government revenue through tax money exchange activity.

The data and mapped them with micro-and macroeconomic indicators of the country that proves the lack of Ukraine exchange market segment, despite a record number of business organizations called "exchange" that would carry inherent important market function.

The list of problems of exchange activities in Ukraine and the need for a clear mechanism of state regulation of exchange activity. Attention is paid to the need for a unified exchange system in Ukraine by international experience.

Key words: agricultural market, stock exchange, stock trading, exchange agreements, regulatory support, the stock market, commodity exchange.

\section{Вступ}

Розвиток суспільно-економічних відносин на основі становлення ринкового середовища і відносин власності потребує створення відповідної інфраструктури ринку, що формується завдяки взаємодії комерційних та інвестиційних банків, лізингових і страхових компаній, торговельних домів і палат, оптовороздрібних організацій, бірж, аукціонів, виставок, брокерських контор, маркетингових, консалтингових, юридичних та аудиторських компаній (Kulyk, 2008; Bondarchuk, 2009). В Україні біржова діяльність хоч і має позитивну динаміку останніх періодів по багатьох показниках, що іiї характеризують, все ще перебуває на стадії становлення. Особливого впливу на біржову ситуація має теперішня економічна криза, що викликана нестабільною політичною ситуацією у країні. Подальший розвиток агросфери неможливий без наявності науково обгрунтованих механізмів збуту сільськогосподарської продукції, зокрема без відповідних організацій, які у розвинених країнах стали важливою частиною інфраструктури аграрного ринку, та без яких немислиме існування ринково орієнтованої економіки. Серед таких організацій важливе місце займають біржі.

\section{Результати та їх обговорення}

Особливе місце в інфраструктурі сучасної ринкової економіки посідають біржі. Біржові інституції функціонують не одну сотню років. Формування ринкової економіки викликало нагальну необхідність створення таких інституцій. Зважаючи на світовий досвід і сучасні тенденції їх діяльності, з урахуванням вітчизняних особливостей, 1992 р. Верховна Рада
України прийняла Закон України «Про товарну біржу», що забезпечило передумови для динамічного розвитку національного біржового аграрного ринку.

Товарна біржа це організований, постійно діючий ринок масових, стандартизованих, замінних товарів та товарних деривативів, на якому в умовах вільної конкуренції формуються ціни, здійснюється їх котирування, забезпечується деперсоніфікація й публічність торгу та забезпечується зниження трансакційних витрат та зниження ризиків невиконання угод.

Становлення біржової торгівлі у світі відбувалося 3 ініціативи купців (історично спочатку з'явилися брокери, потім біржі), а іiі подальший розвиток та удосконалення були зумовлені потребами економіки країни і здійснювалися одночасно з їі ростом. В Україні ж відродження товарних та інших бірж відбувалося штучно (спочатку біржі, потім брокери) в період різкого спаду економіки, за відсутності єдиного правового поля, що породило безліч негативних проявів у їх діяльності (Kulyk, 2008; Naumenkova, 2009).

Таблиия 1

\begin{tabular}{|c|c|c|c|c|c|}
\hline \multicolumn{6}{|c|}{ Кількість бірж * } \\
\hline & $\begin{array}{c}\text { Всього } \\
\text { зареєст- } \\
\text { ровано }\end{array}$ & $\begin{array}{l}\text { Універ- } \\
\text { сальні }\end{array}$ & $\begin{array}{l}\text { Товарні та } \\
\text { товарно- } \\
\text { сировинні }\end{array}$ & $\begin{array}{c}\text { Агроп- } \\
\text { ромис- } \\
\text { лові }\end{array}$ & Інші \\
\hline 2013 & 574 & 108 & 400 & 24 & 42 \\
\hline 2014 & 586 & 107 & 415 & 23 & 41 \\
\hline 2015 & 555 & 104 & 391 & 24 & 36 \\
\hline
\end{tabular}

Станом на 1 жовтня 2013 року було зареєстровано 574 біржі, з яких: універсальних 108 (18,49\%), товарних і товарно-сировинних $400(70,21 \%)$, агропромислових 24 (4,11\%), інших - 42 (7,19\%). При цьому 
повноцінно функціонували 3 них менше половини. Станом на початок 2015 року в Україні (без урахування тимчасово окупованої території Автономної Республіки Крим і м. Севастополя та частини зони проведення антитерористичної операції) налічується 555 (без урахування фондових бірж). Ефективно змогли функціонувати лише 113 них [1]. Однак навіть ця кількість є занадто високою для країни з такою територією і обсягом бізнесових угод. Варто зазначити, що у багатьох країнах світу функціонує тільки одна біржа, наприклад, Швеція, Швейцарія, Нідерланди; в Англії тільки 5 бірж, а у США 11 фондових і 30 товарних.

За I квартал 2015 року на біржах України було проведено 1,7 тис. торгів, на яких для продажу запропоновано товарів на суму 6,8 млрд. грн.. і укладено 16,3 тис. угод на суму 6,3 млрд. грн. Для порівняння за I квартал 2012 року на біржах України було проведено 1,4 тис. торгів, на яких для продажу запропоновано товарів і послуг на суму 26,9 млрд. грн.. і укладено 15,4 тис. угод на суму 26,4 млрд. грн.. Середній обсяг торгів на товарних біржах України в I кварталі 2014 року знизився у п’ять разів у порівнянні з аналогічним періодом минулого року і склав 3,6 млн. грн. Про це свідчать дані Державної служби статистики України. Найбільший обсяг угод у січні-березні цього року було укладено на агропромислових біржах $(59,8 \%)$ і на товарно-сировинних і товарних біржах (30,3\%). На універсальній біржі обсяг угод склав всього 9,9\% від загального обсягу біржових угод.

Загалом по даним Держкомстату найбільший коефіцієнт ліквідності спостерігався на біржах нерухомості $(100 \%)$, агропромислових $(97,5 \%)$, універсальних $(93,6 \%)$, товарно-сировинних і товарних біржах $(85,3 \%)$.

Як свідчить світовий досвід, біржі створюються тільки у великих ділових центрах. В Україні біржова діяльність начебто здійснюється у всіх регіонах. Однак, незважаючи на те, що біржова діяльність поширена в усіх регіонах України, разом з тим, на біржах, що діють в чотирьох регіонах України було укладено 92,7\% усіх біржових угод. Найбільша частка біржових угод припадала на біржі Києва $(79,7 \%)$, Полтавської (7,2\%), Київської (4\%) та Дніпропетровської $(1,8 \%)$ областей.

Аналізуючи наведені дані та зіставляючи їх 3 мікро- та макроекономічними показниками діяльності нашої країни можна сказати, що в Україні відсутній сегмент біржового ринку, не зважаючи на рекордну кількість підприємницьких організацій 3 назвою «біржа», який виконував би притаманні йому важливі ринкові функції.

Діяльність біржі потребує чіткого механізму державного регулювання. Вона регламентується актами та контролюється державними й громадськими комісіями. До цього часу товарні біржі в Україні не посіли належного місця, як того вимагають нові економічні умови, що викликає необхідність переосмислення їх сутності та призначення, розробки науково обгрунтованих пропозицій щодо формування ефективного біржового механізму, сприятливих організаційних і правових умов їх функціонування. Та- кож на діяльність бірж в Україні останнього року досить істотно вплинула політична ситуація, погіршення економічного стану у зв'язку з конфліктом на сході країни. Однак вплинути на ці фактори можна тільки політичними факторами.

Оскільки перелік проблем розвитку біржової діяльності в Україні є досить значним і описати ретельно кожну з проблем у межах однієї статті неможливо, на нашу думку доцільно виділити головні з них. Отже основними проблемами, які уповільнюють розвиток біржової діяльності в Україні, за винятком політичних, $€$ наступні: незначна частка організаційного ринку, низький рівень ліквідності, проблема прав акціонерів і захисту інвесторів, нормативне регулювання, недостатність податкового стимулювання, непрозорість ринку, відсутність біржової культури та недостатня кількість професіоналів;

\section{Висновки}

Отже, у процесі розвитку біржової торгівлі, відповідно до світового досвіду та національних особливостей України, подальший розвиток біржового ринку повинен відбуватися у напрямку створення єдиної біржової системи в Україні, для чого необхідно: оптимізувати кількість бірж, забезпечити ефективне регулювання біржової діяльності шляхом створення комісії з біржового товарного ринку України та розрахунково-клірингових установ, покращити систему моніторингу кон'юнктури біржового ринку, висвітлювати котирування не лише фактичних біржових цін, а й прогноз на наступні місяці, розробити і запровадити систему економічних заходів, спрямованих на стимулювання виробників до реалізації сільськогосподарської продукції через прозорі процедури біржового ринку.

Перспективи подальших досліджень. Багато питань подальшого розвитку біржової діяльності залишаються не вирішеними. Зокрема це питання нівелювання впливу зовнішніх політичних та економічних негативних факторів на розвиток бірж та проблеми вдосконалення нормативно-правового регулювання біржового ринку. Швидка плинність економічного життя зумовлює необхідність постійного вивчення практичного досвіду біржової діяльності стосовно сільського господарства та поглиблення надбань науки.

\section{Бібліографічні посилання}

Bondarchuk, Ju.P. (2009). Vynyknennja instytutiv birzhovoi' torgivli $\mathrm{V}$ Ukrai'ni. Visnyk Kirovograds'kogo nacional'nogo tehnichnogo universytetu. 9. 122-126 (in Ukrainian).

Kulyk, A. (2008). Rol' birzhi v realizacii' sil's'kogospodars'koi' produkcii'. Agrarna ekonomika. 12(1), 117-121 (in Ukrainian).

Naumenkova, S.V. (2009). Zarubizhnyj dosvid organizacii' system reguljuvannja j nagljadu za dijal'nistju finansovyh ustanov. Finansy Ukrai'ny. 12. 20-27 (in Ukrainian).

Стаття надійшла до редакиії 2.09.2016 